\title{
INVESTIGATING STUDENTS' CRITICAL THINKING SKILL IN CHEMICAL EQUILIBRIUM USING THE DISCOVERY LEARNING
}

\author{
Fajarisma Izzatul Nadia ${ }^{1}$ dan Endang Widjajanti Laksono ${ }^{2}$ \\ ${ }^{1}$ Magister of Chemistry Education, Yogyakarta State University, Yogyakarta, Indonesia \\ ${ }^{2}$ Department of Chemistry Education, Yogyakarta State University, Yogyakarta, Indonesia \\ email: Fajarisma.nadia@gmail.com
}

\begin{abstract}
This study aimed to determine the effect of discovery learning on the students'critical thinking skill. The research was a comparative study with 64 students of 11 th grade that were randomly selected from senior high school in Yogyakarta. The data of critical thinking was collected through the critical thinking test instrument. Face content and construct validity conducted as initial step in developing the instrument before the test was used to measure students' critical thinking skill toward the research sample. The instrument went through the R\&D for examining its validity and reliability using the Partial Credit Model with the result of validity showed 8 of 10 items fit with model. The study analysis was conducted using t-test and descriptive analysis. The results of this study show there was a significant difference in students' critical thinking between the experiment and control group. The profile results of critical thinking skill indicate that indicators of problem identification were better compared to other indicators learning.

Keywords: critical thinking skill, chemical equilibrium, discovery learning
\end{abstract}

\section{INTRODUCTION}

Nowadays, the learning system has changed from teacher-centered into studentcentered approach. In teacher-centered learning, the acquisition of information occurs in one direction into students. In the other hand, students are actively involved in learning process, performing a discussion in class, identifying information, analyzing and making conclusion to gain knowledge in students-centered learning (Yilmaz, 2017). Thus, students must have critical thinking skill that needed in the process of learning. In addition, critical thinking is an important aspect in strengthening the learning system in the Indonesian national curriculum of 2013, considering this skills are needed for students in confronting globalization challenges both today and in the future.

Several studies have been done to reveal that critical thinking become an essential skill in $21^{\text {st }}$ century education (Changwong et al., 2018). In education, critical thinking relates in finding and digging information activities that promote students' thinking skill (Peter, 2012). These skills are a component of higher order thinking skill, which uses as basic arguments in developing logical and cohesive reasoning. Hence, students are able to understand and apply knowledge learned in various perspectives. Developing critical thinking skill is important for students, but in fact, the learning process in classroom does not support these skills. As a consequence, aligns with result of TIMSS (trends in international mathematics and science study) in 2015 revealed that the average cognitive score of Indonesian students in reasoning domain was in the $4^{\text {th }}$ position from the bottom which indicated students' critical thinking were in low position. 
Critical thinking is not an innate skill of students, but it is a skill that must be trained by solving a problem in a different perspective and practiced with a question that requires a reason. Those learning activities that help students develop their critical thinking are provided in studentcentered learning (Changwong et al., 2018). According to the research conducted in Indonesian by Muhlisin et al. (2016) reported that critical thinking students are at low level. It could be caused by the teachercentered approach that applied in learning, so it did not encourage the development of students' critical thinking skill. In teachercentered students' inability in giving arguments, lack of interest in reading and incompetence students in giving relevant evidence (Muhlisin et al., 2016). Students are not given the opportunity to be actively involved in conducting investigations. Therefore, teacher must be aware how to promote this skill to produce the character of students who are capable to think critically in each process of learning, precisely in chemistry.

Chemistry is part of scientific knowledge that is abstract and complex characteristics. So it makes chemistry considered as not easy to understand by students. Chemical equilibrium is one of the chemistry topics that include many concepts relate to daily life, for instance, an application of Le Chatelier principle in industrial (Ebbing \& Gammon, 2009, p. 610). Some problems in understanding chemical equilibrium are reported by Sirhan (2007). Misunderstanding in identifying chemical equilibrium, misconception in understanding Le Chatelier principle and inability to predict constant equilibrium value were some problems of students' conception.

Learning chemistry should assist students to improve their cognitive process through experience in finding and designing experiment to get meaningful knowledge (Bada \& Olusegun, 2015). So, these difficulties can be overcome by providing better and effective learning experience. Many efforts have been done to enhance students' critical thinking skill. In accordance with the previous study, it is found that critical thinking can be improved through applying discovery learning model (Joy, 2014). Discovery learning is a part of constructivist learning that focuses on giving meaning to students through the process of assimilation and accommodation in strengthening their cognitive structure. Discovery is a basic form of inquiry-oriented learning that focuses on building knowledge inductively from experiences and using reflection as a key of understanding. Discovery learning, inquiry and problem solving have the same principles between them. The differences in discovery learning is more emphasized on the concept discovery or principle that are not previously known and the problem learned can be designed by teacher (Carin \& Sund, 1989, p. 104). In applying this learning, students find a knowledge by their own effort in determining the problem solution in learning.

The role of discovery learning model in this research is to support the critical thinking students. Discovery learning model could stimulate students' critical thinking because students discover the facts and chemical principles by their own abilities, students will construct their understanding through observation, exploration, investigation, and problem solving activities (Azer et al., 2013). However, it need a profound analysis in which indicator of critical thinking as the best in the applying discovery learning. From the above overview on the importance of critical thinking skills, the researchers 
sought out to know: How is the profile of students' thinking skills between discovery model and traditional model groups in the chemical equilibrium topics, is there a difference between the two?

Through this research, researchers investigate whether there is any significant difference in students' critical thinking skill using the discovery learning between the two groups or not. Also, we provide the information about specific skills developed using the discovery learning model that contributes to students' critical thinking skills.

\section{METHODS}

This research used quasi experiment method. The sample of this study was chosen from one of senior high schools in Sleman regency, Indonesia. The sample was selected by use of random sampling from four classes. The forth classes have equality on students' initial knowledge. There were 64 students of 11st grade enrolled in the second semester of Academic Year 2020. The sample of study was classified into two groups which were experiment $(\mathrm{N}=32)$ taught by discovery learning and control group $(\mathrm{N}=32)$ taught by traditional learning.

According the aims of this research, the data collection was obtained through critical thinking skill test of chemical equilibrium topic. The instrument consists of 10 essay items that have been developed by researcher refers to critical thinking indicators (Facione, 2013, p. 5; Bowell \& Kemp, 2009). Indicator was used to measure students' critical thinking in this research is a modification from FacioneBowell and Kemp's indicators that includes identification, reconstruction, analysis, evaluation, and conclusion.

Face content and construct validity conducted as initial step in developing the instrument before the test was used to measure students' critical thinking skill toward the research sample. Face validity was conducted to determine the appropriateness of the instrument content through expert's judgment. The result of their feedback is used as a basic for improving contents of the instrument for further step. Furthermore, the construct validity successfully conducted by giving instrument toward 134 students. The step in analyzing the construct validity is partial credit model. The Partial Credit Model (PCM) analysis consists of test assumption unidimensionality and item fit. In addition, the instrument reliability estimation is also conducted.

The data obtained were analyzed using exploratory factor analysis with the assistance of the SPSS and Winsteps program. The Exploratory factor was carried out to identify the relationship between aspects of the variable that measured. Kaiser-Meyer-Olkin (KMO) and Bartlett's Test were conducted to ascertain whether the data are compatible with an exploratory factors (Kaiser, 1970). Beavers et al. (2013) stated that the test value received is greater than 0.6 for the KMO value (Kaiser-Meyer-Olkin) and Bartlett's Test significant value was smaller than 0.5 . The result of the KMO value was found $0.818>0.6$, which means the data was compatible for factor analysis. The Bartlett's test of sphericity was found $x 2=$ 626.306 and the significant at $0.00<0.5$, which indicates that the analysis of the adequacy of the sample was fulfilled and further analysis can be conducted.

Unidimensionality assumptions conducted by observed total Eigen value. The percentage of Eigen value matrix correlation was obtained was $45.13 \%$ greater than $20 \%$. According to Brown et al. (2016), if the result of output Eigen value in first factor more than $20 \%$, then 
the assumption of unidimensionality has been fulfilled. Item fit is carried out to assess whether the item has been adequate or not. The value received of the criteria used to check the suitability of the items is as follows: (a) $0.5<$ Outfit $\mathrm{MNSQ}<1.5$; (b) $-2.0<$ Outfit ZSTD $<+2.0$; and (c) $0.4<\mathrm{Pt}$ Measure Corr $<0.85$ (Boone et al., 2014, p. 166). The result of item fit indicated 2 of 10 items test not fitting the model based on criteria suggested by Boone et al., (2014, p. 166). The reliability result of this instrument shows that estimated value for Alpha Cronbach's was 0.75 which can be conducted that the reliability of instrument test was moderate reliable category (Hair et al., 2010, p. 123). Based on analysis of construct validity, item fit, and reliability, the item of instrument is used in collecting critical thinking skills consist of 8 items that fit with this the model.

This study used SPSS and Excel, a quantitative data analysis software. The researcher conceptually analyzed the data through: Conducting $t$-test analysis after applied learning models in experiment and control group to determine whether there are differences in students' critical thinking or not; Categorizing students' critical thinking in accordance with quantitative data analysis for each group based on result of critical thinking test; Performing descriptive analysis based on data of critical thinking instrument for each group in order to present the students' critical thinking profiles. The researcher also conducted a manual reading and analysis of student's answer to enhance the finding.

\section{FINDINGS AND DISCUSSION}

Before $t$-test is used, the normality and homogeneous conducted in fulfilling the assumption of $t$-test. The result of Shapiro-wilk is obtained a significant value of $0.271>0.05$ which means that the data are distributed normally. Furthermore, the result of Levene's test was obtained at sig. Value of $0.869>0.05$ which means the data is declared as homogeneous. After the two assumptions had been fulfilled, the independent $t$-test can be conducted. Based on the data obtained by experimental and control group, the students' mean and standard deviation for critical thinking score for both groups were shown in Table 1 .

The independent $t$-test was used to know whether there was a statistical difference mean between critical thinking skills in the experiment group which applied discovery learning and the control group which applied traditional learning at 0.05 levels. Based on the mean result, students' critical thinking that was taught by discovery learning was higher than traditional learning. This finding is in line with Balim's (2009) which stated that in applying discovery learning in students' critical thinking, it requires to do discussion and ask question to get an information for themselves. Besides, the ability of students' connectivity is also needed in finding solution to a problem (Kusumadewi \& Rosnawati, 2020).

Based on result of independent $t$-test, the value of sig. (2-tailed) $=0.00 ; p<0.05$ which means null hypothesis is rejected. So, it can be concluded that there is a

Table 1

The Descriptive Statistic for Experimental and Control Groups

\begin{tabular}{lccc}
\hline \multicolumn{1}{c}{ Group } & $\mathrm{n}$ & Mean & Standard Deviation \\
\hline Experimental Group & 32 & 58.79 & 9.767 \\
Control Group & 32 & 49.22 & 9.722 \\
\hline
\end{tabular}


significant average difference between students who implemented the discovery learning model and traditional learning. The experiment group gets the highest meanvalue. It reveals that the implementation of discovery learning promotes better critical thinking skills toward students.

The students' critical thinking data is obtained from critical thinking test. The classification of students' critical thinking is based on the percentage in each category of both group. The critical thinking data is in the average in each indicator, then it is classified into the category based on ideal rating category suggestion by Miller et al. (2009). The instrument with total eight items has 4 as maximum score for each item, thus in total will be 32 as ideal maximal score and 8 as ideal minimal score. The ideal rating category is conducted to classify students into five categories. The total of students in all category is calculated and the results is turn into the percentage in each category. The five rating categorized include: as very good critical thinking if the value of $X>27.2$; good category in the range of $22.4<\mathrm{X} \leq 27.2$; medium category in the range of $17<\mathrm{X} \leq 2.4$; low category in the range of $12.8<\mathrm{X} \leq 17.6$; and very low category if the $X \leq 12.8$. Then, the total of student in each category is calculated and the percentage is determined. The result of percentage compared between both of group (Figure 1).

Based on Figure 1 it can be concluded that there are experiment students in the very good category while the control students are not. The development of students' critical thinking skills caused by a sequence of activities in the active learning process (Winarti et al., 2019). Activities in discovery learning such as identifying problems, expressing opinions, and generalizing are part of an effort to improve critical thinking skills. This causes the experimental group to experience an increase in critical thinking skills compared to the control group. This result has reported in Kusumadewi and Rosnawati (2020, p. 294) stated that activity in discovery learning increasing self-confidence students to solve the problem given.

Other hands, there are not many activities that support the development of students' critical thinking skills in traditional learning. It aligns with the

\section{Figure 1}

The Profile of Students' Critical Thinking Based on Percentage of Category

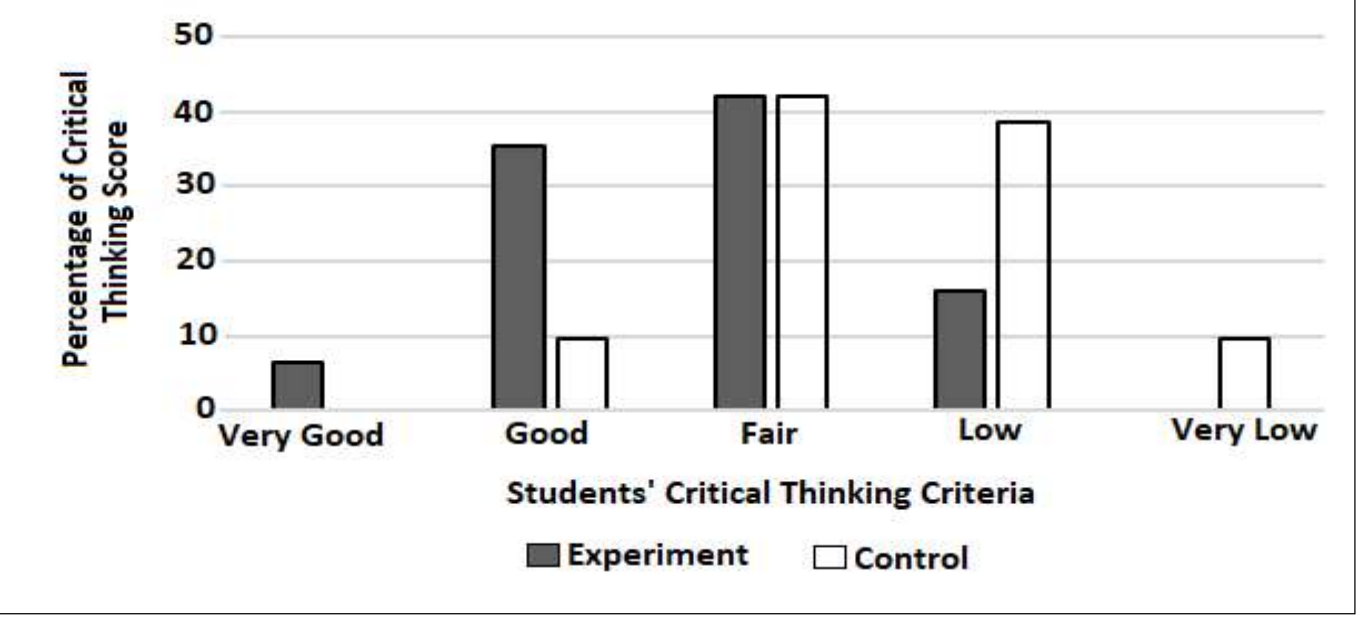


argument of Swaak et al. (2004) that explained students' skills and activities in traditional learning are limited because basically students only have reading and memorizing activities. In addition, lack of student intelligence can be a factor in leading the low of students' critical thinking skills. This finding is supported by the results of Adeyemi' study (2012) that mention if someone practicing his critical thinking requires intellectual and cognitive abilities. Students with low critical thinking are easier to accept ideas without reviewing the truth. In other words, when students are not more active and persistent in the learning process, critical thinking does not develop optimally. In the sense of building students' critical thinking, it can be done by maximizing student activities and minimizing the dominance of teacher in learning activities

The third result in analyzing profile of students' critical thinking skill is a review based on percentage of critical thinking indicator. The critical thinking skill has five indicators namely identification, reconstruction, analysis, evaluation, and conclusion. All scores obtained by students for each indicator are converted to percentage then classified. Then, the percentage in each indicator of both groups was compared. In order to show the visualization of the students' critical thinking skills distribution can be can be seen in Figure 2 .

The results of analysis students' critical thinking skills profiles in experiment group reveal that skill of identifying problems is an indicator mastered by students (62\%). This is due to the discovery learning process, students are given a stimulus in the form of problems, pictures, graphics or data that requires students to identify the focus of the problem. Also, Balim (2009) states that in implementing discovery learning, students are given the opportunity to give their opinions on the concepts or principles they get through discussion and question answer. Hence, through this activity students are accustomed to investigating and finding solutions of the problems.

The indicator making conclusions is the lowest percentage obtained by students compared to other critical thinking indicators. This can be caused by the lack of students' knowledge in understanding concepts. Sirhan (2007) state that students'

Figure 2

The Profile of Students' Critical Thinking Based on Critical Thinking Indicator

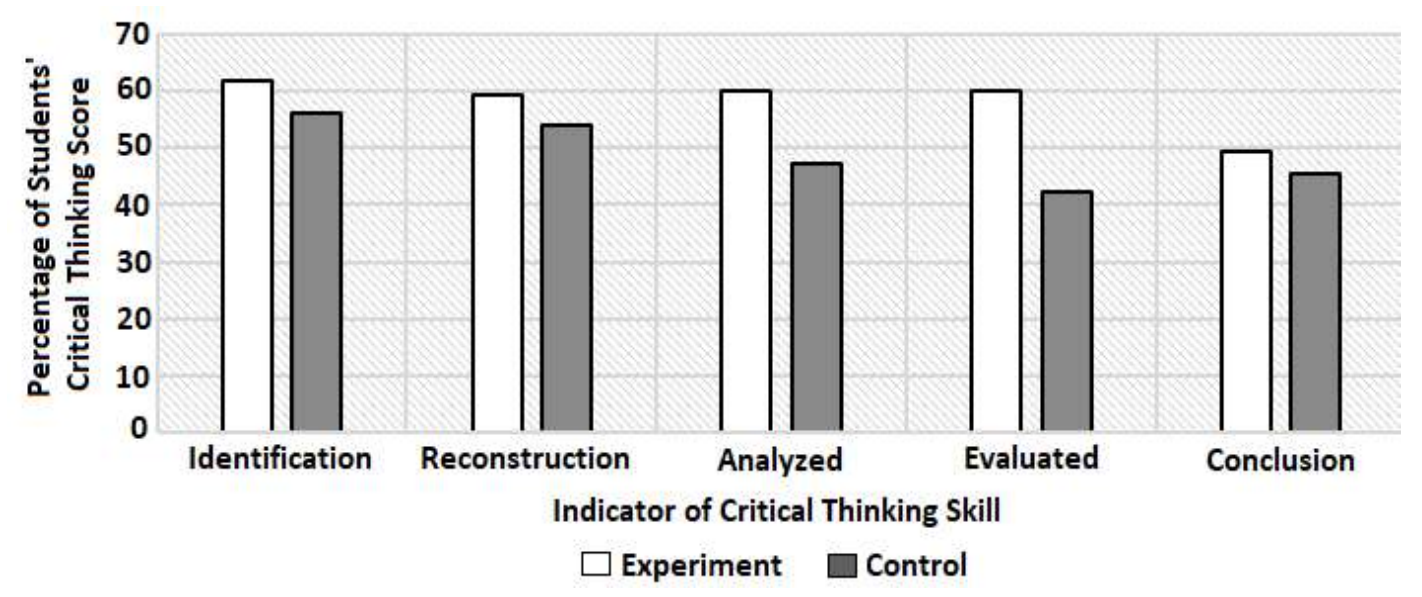


lack of knowledge on the concept of chemical equilibrium can be an obstacle in solving problems. Beside, Student constraints caused by the inability of students to do the analysis. This statement is explained by Tuzlukova and Prabhukanth (2018) that the analysis is a series of processes that lead to conclusions, and the conclusion becomes a path for evaluation activities and continues to the assessment and decision making. So the quality of a decision that is made by students depends on a series of critical thinking done by students in which intellectual knowledge takes part in the sequence. On the other hand, the low ability of students' critical thinking skills in the control group due to students not accustomed to learning by using problems that require critical thinking. This statement is reinforced by Snyder and Snyder (2008) asserting that students in traditional learning focus on the acquisition of knowledge one of them through memorization methods that cannot improve students' critical thinking skills. In order to confirm the profile of students 'critical thinking, students' responses of problem identification and evaluated information skill would be discussed in the section below:

Further, the indicator of problem identification was analyzed between experiment group and control group and the results are discussed below. The ability to think critically in identifying a problem is followed by the ability of constructing argument. Mumford (2003, p. 110) stated that identification of problem is an important factor in promoting creativity. Thus, students requires to think in finding idea and expressing it in the form of argument. So, analyzing skill can be seen based on the arguments that were established to explain their identification. The question in identifying problem is defined in item 1.

\begin{abstract}
Item 1
This item involved a decomposition of equilibrium reaction of $\mathrm{N}_{2} \mathrm{O}_{4}(\mathrm{~g})$ $2 \mathrm{NO}_{2}(\mathrm{~g}) \Delta \mathrm{H}=+\mathrm{X} \mathrm{kJ}$ (endotherm). There are indication of chemical equilibrium state in the phenomenon of decomposition reaction. Students were asked to identify the chemical equilibrium state that occurs in that reaction.
\end{abstract}

Student responses to questions reflect their ability to identify phenomena by applying knowledge that has been learned. Although the students of experiment group have a percentage of $62 \%$ for this indicator achievement, there were differences in how students answer the question between students who are classified as high, medium and low critical thinking skill. Therefore, it will be described the differences in quality of experiment students' responses. As comparison, students' response of control group is used as well. Before trying to solve this question, students must understand the meaning of equilibrium state. Students can identify the equilibrium state in other phenomenon given using that knowledge. The examples of students' responses in solving this problem are discussed below (Figure 3).

Figure 3 shows experiment students' response in very high category of critical thinking skill (Student 5). It is the example of the correct answer. Students are able to identify the equilibrium state that occurs in decomposition reaction $\mathrm{N}_{2} \mathrm{O}_{4}(\mathrm{~g}) \rightleftharpoons$ $2 \mathrm{NO}_{2}(\mathrm{~g})$. Based on Figure 3, to solve this problem, students write down the condition of reaction at equilibrium namely reversible reaction where reactant reacts to form the product and product can form reactant, closed system means compound in system can escape, and reach dynamic equilibrium means that the rate of forward and reverse 
Figure 3

Answer by Students 5

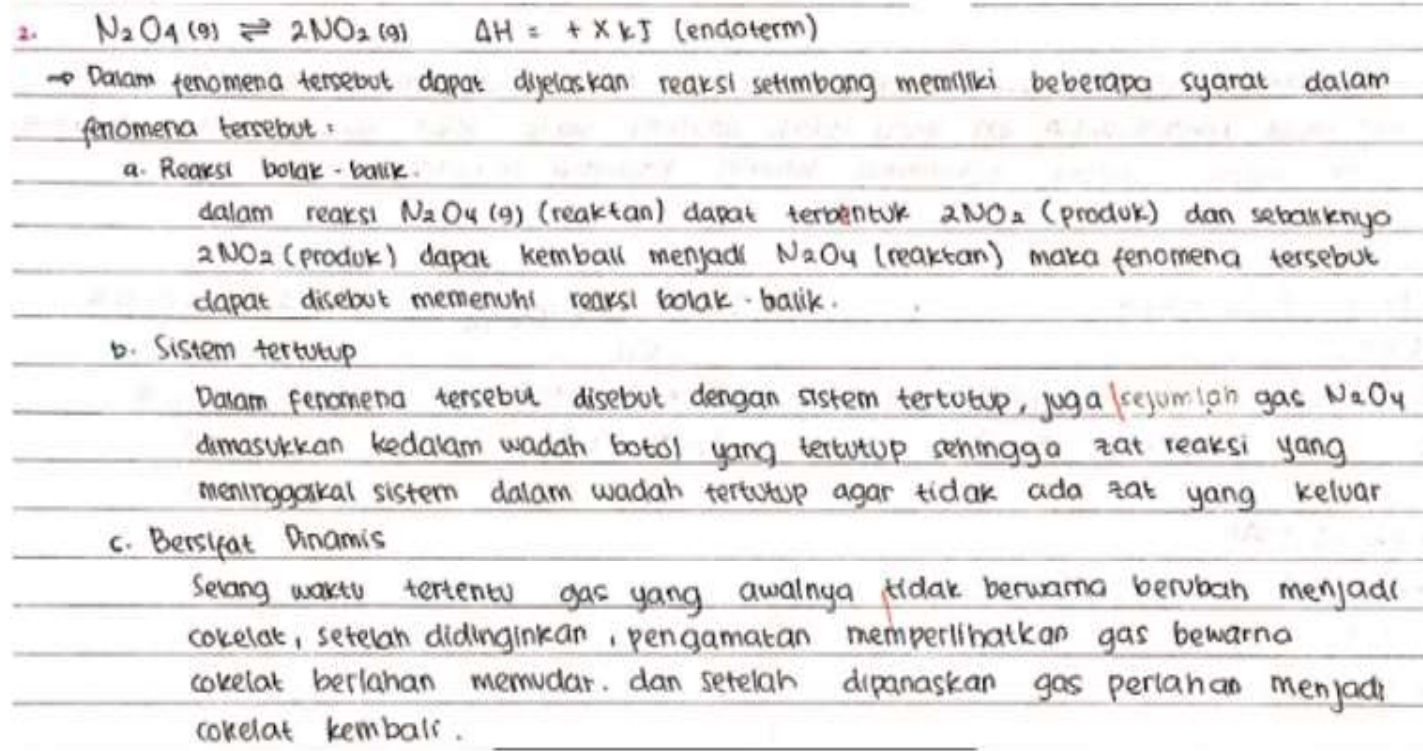

reaction are equals. Furthermore, students are identifying condition equilibrium state in decomposition reaction of $\mathrm{N}_{2} \mathrm{O}_{4}(\mathrm{~g}) \rightleftharpoons$ $2 \mathrm{NO}_{2}(\mathrm{~g})$ given in the question, as indicated in written responses of high category students' given below:

"Color changing was happening in test tube if there was a treatment given in reaction, but in some point in equilibrium reaction of $\mathrm{N}_{2} \mathrm{O}_{4}(\mathrm{~g})$ $\rightleftharpoons 2 \mathrm{NO}_{2}(g)$ that reaction reached equilibrium state while the intensity of brown color was stop changing. It means that the reaction had reached dynamic equilibrium state and the rate of forward reaction was equal to reverse reaction in case reaction of $\mathrm{N}_{2} \mathrm{O}_{4}(\mathrm{~g}) \rightleftharpoons 2 \mathrm{NO}_{2}(\mathrm{~g})$. In addition, the $\mathrm{N}_{2} \mathrm{O}_{4}(\mathrm{~g}) \rightleftharpoons 2 \mathrm{NO}_{2}(\mathrm{~g})$ reaction carried out in a closed test tube indicated that no substance has left the system. So, it can be concluded that this reaction occurred in a closed system".
Student 5 solved the problem more systematically and logically. Student used the results of their experiments by connecting the phenomena (decomposition of $\mathrm{N}_{2} \mathrm{O}_{4}(\mathrm{~g}) \rightleftharpoons 2 \mathrm{NO}_{2}(\mathrm{~g})$ provided with the knowledge they already have. Therefore, student can make argument in describing equilibrium state that happen in given problem. Another student responses who get lower score that student 5 is student 4 .

The students' responses who in medium category can be seen in Figure 4. Even though the students' responses were correct but their arguments were not completely accepted. The example of student's argument in explaining their finding is described in Figure 4. "The reaction of $\mathrm{N}_{2} \mathrm{O}_{4}(\mathrm{~g}) \rightleftharpoons 2 \mathrm{NO}_{2}(\mathrm{~g})$ had double arrows that appear in reaction equation It showed that the reaction had reach equilibrium state. Their arguments were true but that were basic definition to understand the concept of reversible reaction". 
Figure 4

Answer by Students 4

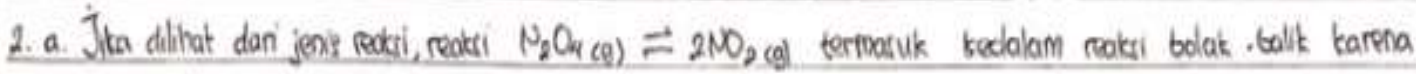

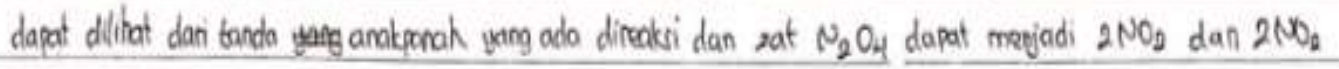
dopat kermaliagi ke $\mathrm{N}_{2} \mathrm{OH}_{\text {. }}$.

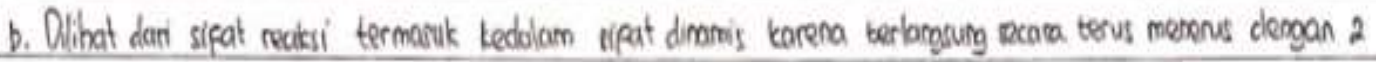
aroh dan laju reaksi $\mathrm{N}_{2} \mathrm{O}_{4}$ samodorgan laju redsi $2 \mathrm{NO}_{2}$

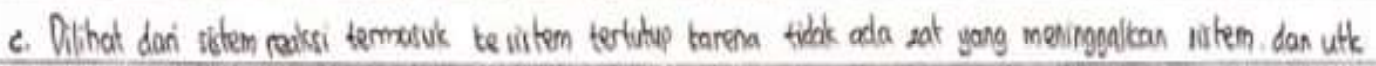

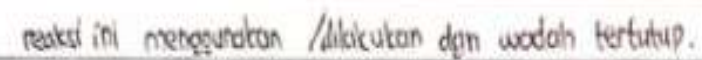

While students' responses in low category get lower scores than two previous students (see Figure 5). Based on Figure 5, students informed their arguments about equilibrium state of $\mathrm{N}_{2} \mathrm{O}_{4}(\mathrm{~g}) \rightleftharpoons 2 \mathrm{NO}_{2}(\mathrm{~g})$ not all correctly. "Decomposition reaction of $\mathrm{N}_{2} \mathrm{O}_{4}(\mathrm{~g}) \rightleftharpoons 2 \mathrm{NO}_{2}(\mathrm{~g})$ occurred in closed system since it reacted in test tube. The reaction of $\mathrm{N}_{2} \mathrm{O}_{4}(\mathrm{~g}) \rightleftharpoons 2 \mathrm{NO}_{2}(\mathrm{~g})$ was dynamic equilibrium which can be seen from the color of reaction".

The lack of explanation given by students reinforces their inability to reconstruct their arguments. Based on students' responses, it can be concluded that implementing discovery learning model leads students more careful in identifying problems because in discovery learning model there are problem identification activity that can enhance student's identification skill (Akani, 2017). In order to clarify the differences of student's critical thinking in experiment and control students, the control students' responses in low category were used as a comparison (Figure 6).

Students are not be able to give explanation about equilibrium state in case of decomposition $\mathrm{N}_{2} \mathrm{O}_{4}(\mathrm{~g}) \rightleftharpoons 2 \mathrm{NO}_{2}(\mathrm{~g})$. Students write down the condition for reaction which reached the equilibrium state which is knowledge of conceptual only, and there are errors in defining the equilibrium state. As indicated in written responses of control students given below:

Figure 5

Answer by Students 30

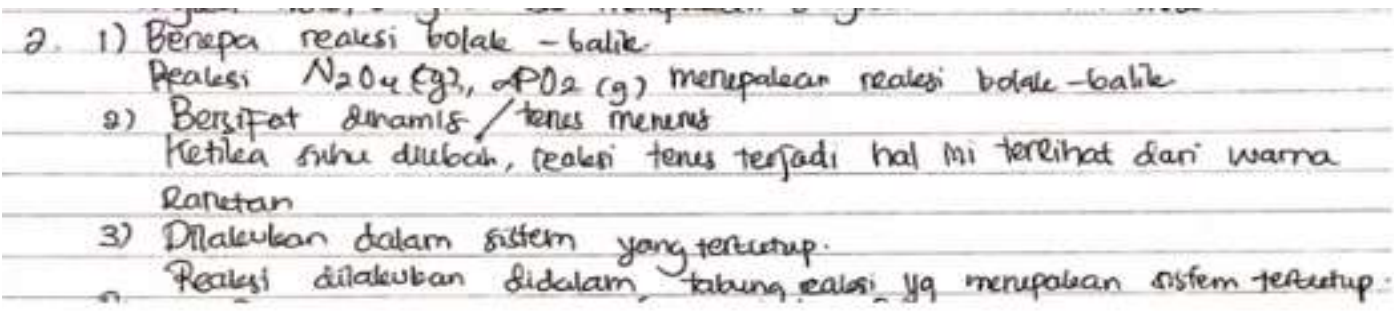


Figure 6

Answer by Students 24

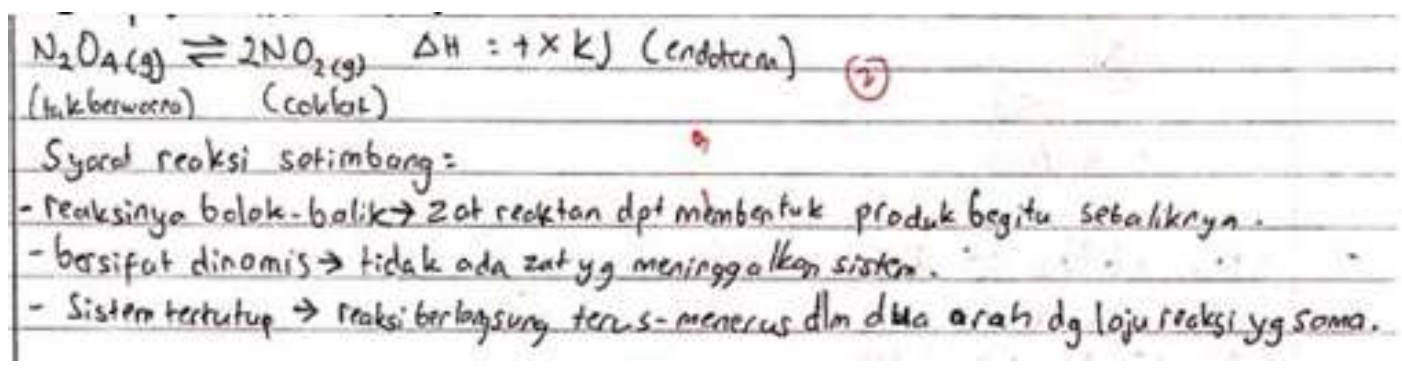

"Reversible reaction meaning that reactants can form products and products can form reactants again and dynamic equilibrium means that no substances leave the system and the closed system means that the reaction takes place continuously in two directions at the equal reaction rate".

The control students did not apply their knowledge to identify the same content in different cases. Students give answers that are theoretical and based on memorizing, resulting in students' inability to evaluate their knowledge, and correlate them with new situation. Researcher assumed that the critical thinking in identification skill of control students is still lacking. Therefore, none of identification skill was conducted by control students. They only understand it insight fully and just memorize the concept. This problem becomes obstacle for students to develop the identification skill maximally.

Indicator of evaluation in critical thinking skill is an assessment process which based on data. It collected to get the information needed to make decision. In evaluating a problem, there are stages that must be accomplished by students, following are; identifying problems, designing evaluation action, collecting data, analyzing data, and producing evaluation result. Ennis (1993) stated that critical thinking includes the process of reasoning in making decision or solving problem. So, the essence of critical thinking skill is mental process in evaluating the truth of statements. The application of critical thinking skill possessed by students by providing the evaluation results on problems in CT test item 3, which requires quantitative reasoning. The experiment students' responses discussed from students who are classified in high, medium and low category. As comparison, the answers of control students also analyzed.

\section{Item 3}

Students were required to predict the reaction at equilibrium when the temperature reaction is changed. This item involved the reaction of sulfur dioxide oxidation, $2 \mathrm{SO}_{2}(\mathrm{~g})+\mathrm{O}_{2}(\mathrm{~g})$ $\rightleftharpoons 2 \mathrm{SO}_{3}(\mathrm{~g})$ at $100^{\circ} \mathrm{C}$, (assumed that in constant temperature) has $K$ value 4.1 $\times 10^{3}$. If at T temperature, the partial pressure of gases are $\mathrm{SO}_{2}: 0.2 \mathrm{~atm} ; \mathrm{O}_{2}$ : $0.1 \mathrm{~atm}$; and $\mathrm{SO}_{3}: 4 \mathrm{~atm}$, is the reaction system has reached equilibrium state?

To evaluate this problem, we need to calculate Q (Quotient) reaction in condition given and compare the value of $\mathrm{Q}$ to 
equilibrium constant $(\mathrm{K})$ and predict the equilibrium state of reaction given. There are concepts that include on this item which is students must understand the concept of equilibrium constant earlier. An equilibrium constant will change if the temperature is changing Chang and Overby (2011, p. 510). The example of students' responses in solving this problem are discussed on Figure 7.

Figure 7 shows the response of control student in fair category of analysis indicator. Students use value of $\mathrm{K}$ (at $100^{\circ} \mathrm{C}$ ) into new expression to calculate value of $\mathrm{Q}$. It shows that students did not understand the concept of $\mathrm{Q}$ and $\mathrm{K}$. $\mathrm{K}$ describes reaction at equilibrium state and $\mathrm{Q}$ describes reaction in not at equilibrium state (Whitten et al., 2010, p. 674). Student ignores the fact that the $\mathrm{K}$ value changes when the temperature of reaction is different. So, in completing new expression of Q, students are hampered because of their lack of understanding. Instead of gaining insight understanding of the concept during learning, they just focus on memorizing the theories. As a result, students can not apply what they have learned in answering the question.

Figure 8 shows experiment students' response is in low category. It started with calculating the expression of the reaction quotient $(\mathrm{Q})$ and comparing the $\mathrm{Q}$ value to the equilibrium constant of $K$. Students understand the concept of $\mathrm{Q}$ and $\mathrm{K}$, knowing the purpose in problem given but students still made mistake in balancing the chemical equation. Their inability causes all answers had been made were wrong. The expression

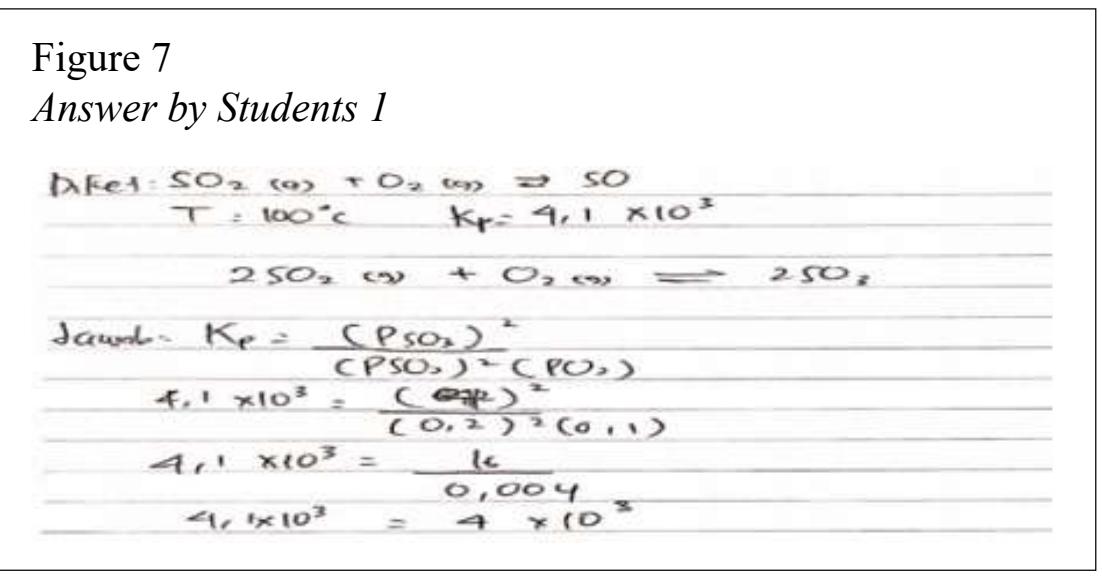

Figure 8

Answer by Students 25

\begin{tabular}{|c|c|}
\hline $\mathrm{CO}_{2}+\mathrm{O}_{2} \leftrightharpoons \mathrm{SO}_{3}$ & KP bary : Kp teah dreetakü \\
\hline $\mathrm{KP}=\left(\mathrm{PSO}_{3}\right)^{\prime}=(4)$ & $200: 4100$ \\
\hline$\left(\mathrm{PSO}_{2}\right)^{\prime}\left(\mathrm{PO}_{2}\right) \quad\left(\mathrm{O}_{2}\right)\left(\mathrm{O}_{11}\right)$ & $1: 20,5$ \\
\hline A & $K_{P}$ boru $<k_{p}$ tran ditetahi \\
\hline Q02 & Jadi sistem tersebat beroda dalam keadoon belum \\
\hline$=200$ & setimbang \\
\hline
\end{tabular}


for equilibrium constant $(\mathrm{K})$ is the partial pressure of product rank coefficient divided by the partial pressure of reactants rank coefficient (Whitten et al., 2010, p. 675). When the reaction coefficient in chemical equation is incorrect then the calculation results are also incorrect. As consequence the conclusion given in problem evaluation is wrong.

In evaluating the problem, understanding concept becomes crucial tool in breaking down the data given. Students can make logical judgment and produce conclusion. The correct understanding of the concept can be seen in Figure 9. The expression of Q were determined correctly and the chemical equation are balanced but the student not giving decision of the problem in their responses. Students are not critical in using their reasoning in evaluating the value of $Q$ and the value of $K$ that they have found. Inability to express reasons caused students to be unable to make decision. In addition, students with a lack understanding of application concept cause the students to have difficulty solving problems given (Wiyarsi et al., 2020, p. 190).

Students who are able to evaluate problems in critical thinking correctly can be seen in Figure 10. It is shows that

Figure 9

Answer by Students 4

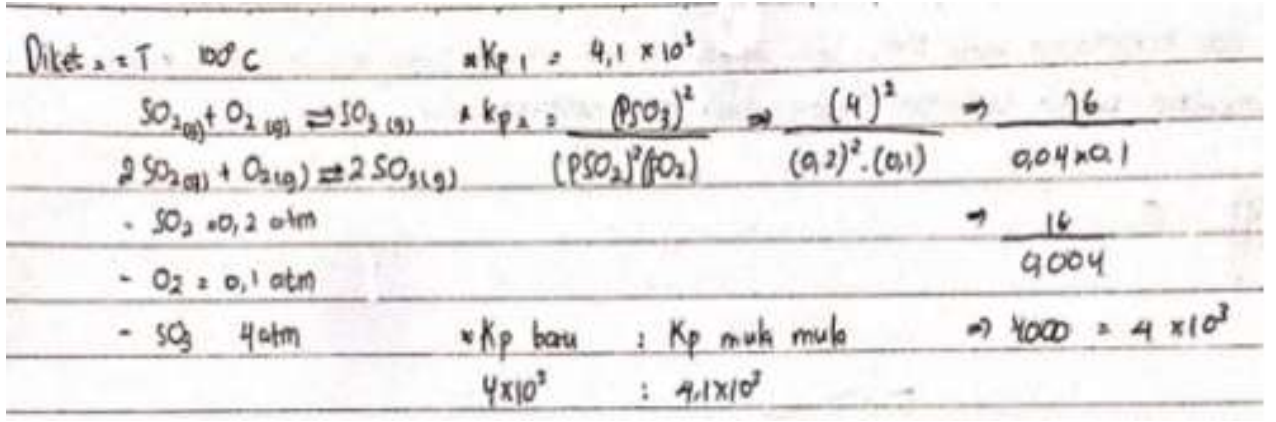

\section{Figure 10}

Answer by Students 21

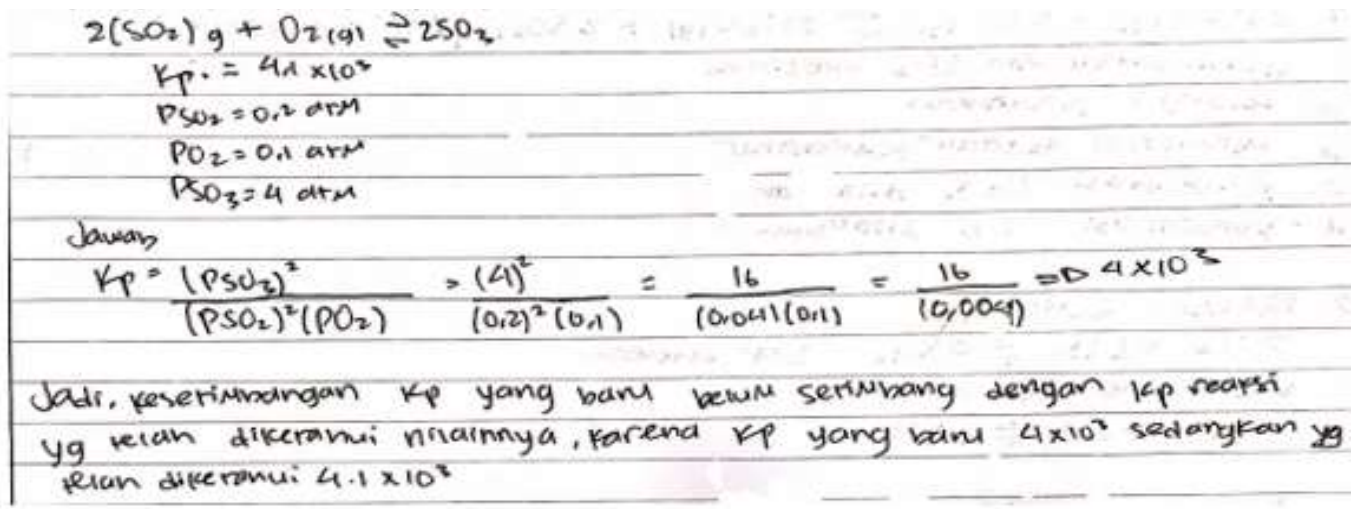


student's response is in good category. Based on students' response, it shows that students understood the concept, analyzed the data correctly and expressed arguments based on data comparison of the $\mathrm{K}$ and $Q$ values, and finally made the decision, which is at $\mathrm{T}$ temperature the reaction given is not at equilibrium state. If we look into sequences of students' answers, students are able to utilize critical thinking skill by understanding the problem, using the information provided as part of problem solution, and assessing information based on the data founded. So students can produce the correct answer.

\section{CONCLUSIONS}

The findings of this study ascertained that there is a significant influence of learning models in critical thinking skill. In short, the student's critical thinking who taught by discovery learning model are higher than students who taught by traditional learning. Based on percentage of indicator critical thinking, it reveals that indicator of critical thinking mastered by students is problem identification with percentage of $62 \%$. The difficulties experience based one the critical thinking test in indicator of concluding the problem with percentage of $49 \%$. The difficulty found in this study is indicated by inability to correlate to their knowledge in other context, misunderstanding of some concept, inability to evaluate their knowledge in solving expressions of the equilibrium constant and inability to reconstruct their arguments. This research needs to be carried out by representing larger number of sample and in various skills which is needed in confronting the challenges of globalization. Furthermore, comparison between critical thinking and other learning models or settings will be useful to measure differences in students' critical thinking profile better.

\section{REFERENCES}

Adeyemi, S. B. (2012). Developing critical thinking skills in students: A mandate for higher education in Nigeria. European Journal of Educational Research, 1(2), 155-161. https://doi. org/10.12973/eu-jer.1.2.155.

Akani, O. (2017). Effect of guided discovery method of instruction and students' achievement in chemistry at the secondary school level in Nigeria. International Journal of Science Research and Education, 5(2), 6232. https://doi.org/10.18535/ijsre/v5i02.06.

Azer, S. A., Guerrero, A. P. S., \& Walsh, A. (2013). Enhancing learning approaches: Practical tips for students and teachers. Medical Teacher, 35(6), 433-443. https://doi.org/10.3109/014 2159x.2013.775413.

Bada \& Olusegun, S. (2015). Constructivism learning theory: A paradigm for teaching and learning. IOSR Journal of Research \& Method in Education, 5(6), 66-70. https://doi.org/10.9790/738805616670.

Balim, A. G. (2009). The effects of discovery learning on students' success and inquiry learning skills. Egitim ArastirmalariEurasian Journal of Educational Research, 35, 1-20. https://pdfs. semanticscholar.org/c92b/f85fbf5545d e25f1724f22f948436f107d80.pdf.

Beavers, A. S., Lounsbury, J. W., Richards, J. K., Huck, S. W., Skolits, G. J., \& Esquivel, S. L. (2013). Practical considerations for using exploratory factor analysis in educational research. Practical Assessment, Research \& Evaluation, 18, 1-13. http://pareonline. net/pdf/v18n6.pdf

Boone, W. J., Staver, J. R., \& Yale, M. S. (2014). Rasch analysis in the human sciences. Springer. https://doi. org/10.1007/978-94-007-6857-4 
Bowell, T., \& Kemp, G. (2009). Critical thinking: A concise guide ( $3^{\text {rd }}$ ed.). Routledge.

Brown, R. L., Obasi, C. N., \& Barret, B. P. (2016). Rasch analysis of the WURSS-21 dimensional validation and assessment of invariance. Journal of Lung, Pulmonary \& Respiratory Research, 3(2), 46-53. https://doi. org/10.15406/jlprr.2016.03.00076.

Carin, A. A. \& Sund, R. B. (1989). Teaching Science through discovery ( $6^{\text {th }}$ ed.). Merrill Publishing Company.

Chang, R., \& Overby, J. (2011). General chemistry: The essential concepts $\left(6^{\text {th }}\right.$ ed.). Mc Graw Hill Higher Education.

Changwong, K., Sukkamart, A., \& Sisan, B. (2018). Critical thinking skill development: Analysis of a new learning management model for Thai high schools. Journal of International Studies, 11(2), 37-48. https://doi. org/10.14254/2071-8330.2018/11-2/3.

Ebbing, D. D. \& Gammon, S. D. (2009). General chemistry $\left(6^{\text {th }}\right.$ ed). Houghton Mifflin Company.

Ennis, R. H. (1993). Critical thinking assessment. Theory into practice, 32 (3), 179-186. https://doi. org/10.1080/00405849309543594.

Facione, P. A. (2013). Critical thinking: What it is and why it count. Measured Reasons and The California Academic Press. https://www.nyack.edu/files/ CT_What_Why_2013.pdf

Hair, J., Black, B., Babin, B., Anderson, R. \& Tatham, R. (2006). Multivariate data analysis ( $6^{\text {th }}$ ed.). Prentice-Hall.

Joy, A. (2014). Impac of discovery-based learning method on senior secondary school physics. IOSR Journal of Research \& Method in Education, 4(3), 32-36.http://www.iosrjournals.org./

Kaiser, H. F. (1970). A second-generation little jiffy. Psychometrika, 35(4),
401-415. http://dx.doi.org/10.1007/ BF02291817.

Kusumadewi, C. A., \& Rosnawati, R. (2020). Optimization guided discovery learning to improve students self confidence in mathematics learning. Jurnal Kependidikan, 4(2), 282-294. https://journal.uny.ac.id/index.php/jk/ article/view/30182/pdf.

Miller, M. D., Linn, R. \& Gronlund, N. E. (2009). Measurement and assessment in teaching. Merrill/Pearson.

Muhlisin, A., Susilo, H., Amin, M., \& Rohman F. (2016). Improving critical thinking skills of college students through RMS model for learning basic concepts in science. Asia-Pacific Forum on Science Learning and Teaching, 17(1), 1-8. https://www. eduhk.hk/apfslt/v17 issue1/muhlisin/ index.htm.

Mumford, M. D. (2003). Where have we been, where are we going? Taking stock in creativity research. Creativity Research Journal, 15, 107-120. https://doi.org/10.1207/ S15326934CRJ152\&3_01

Peter, E. E. (2012). Critical thinking: Essence for teaching mathematics and mathematics problem solving skills. African Journal of Mathematics and Computer Science Research, 5(3), 39-43. https://doi.org/10.5897/ ajmcsr11.161.

Sirhan, G. (2007). Learning difficulties in chemistry: An overview. Journal of Turkish Science Education, 4(2), 3-20. http://www.tused.org/internet/tufed/ $\operatorname{arsiv} / \mathrm{v} 4 / \mathrm{i} 2 / \mathrm{metin} / \mathrm{tusedv} \mathrm{i} 2 \mathrm{~s} 1 . \mathrm{pdf}$.

Snyder, L. G., \& Snyder, M. J. (2008). Teaching critical thinking and problem solving skills. The Delta Pi Epsilon Journal, L(2), 90-99.

Swaak, J., Jong, T. D., \& Joolingenz, W. R. V. (2004). The effects of discovery 
learning and expository instruction on the acquisition of definitional and intuitive knowledge. Journal of Computer Assisted Learning, 20, 225234. https://doi.org/10.1111/j.13652729.2004.00092.x.

Tuzlukova, V., \& Usha Prabhukanth, K. (2018). Critical thinking and problem solving skills: English for science foundation program students' perspectives. Collection of papers of the faculty of philosophy of the University of Pristina, 48(3), 37-55. https://doi. org/10.5937/ZRFFP48-18664.

Whitten, K., Davis, R., Peck, M., \& Stanley, G. (2010). Chemistry $\left(10^{\text {th }}\right.$ ed.). Brooks/Cole.

Winarti, A., Rahmini, A., \& Almubarak. (2019). The effectiveness of multiple intelligences based collaborative problem solving to improve critical thinking. Jurnal Kependidikan, 3(2), 172-186. https://journal.uny.ac.id/index. php/jk/article/view/24714/pdf.

Wiyarsi, A., Damanhuri, M. I M., \& Fitriyana, N. (2020). Exploring pre-service chemistry teachers' problem solving skills on vocational context-based learning. Jurnal Kependidikan, 4(2), 185-199. https://journal.uny.ac.id/index. $\mathrm{php} / \mathrm{jk} /$ article/view/35302/pdf

Yilmaz, O. (2017). Learner centered classroom in science instruction: Providing feedback with technology integration. International Journal of Research in Education and Science (IJRES), 3(2), 604-613. https://doi. org/10.21890/ijres.328091. 